cross-border investment flows. However, the surge in global capital flows posed new and serious challenges to the developing world such as foreign portfolio investment volatility. This is heightened by decreased returns and higher inflation rates as well as government policy inconsistencies (Mody, Taylor \& Kim 2001). These challenges have continued to attract the interest of investors, economic policy-makers and researchers. Kaltenbrunner and Painceira (2015) and other scholars note that the changing nature of capital flows to developing and emerging markets because of financial integration has exposed these economies to new forms of vulnerability, volatile financial flows and exchange rate fluctuations. This motivated the present empirical investigation of the drivers of variability in foreign portfolio investment flows, particularly in low-income Southern African Development Community (SADC) countries.

Goldstein and Razin (2006) define foreign portfolio investment as the entry of funds into a country when foreigners deposit money in its banks or purchase shares from the country's stock and bond markets. Foreign portfolio investment flows are important because of their links with other macroeconomic parameters in stimulating the economy. Volatility is associated with the behaviour of international investors when they deploy funds for short-term benefit and suddenly withdraw their investment as uncertainty or need arises (Kodongo \& Ojah 2012). Accordingly, volatility in this case refers to uncertainty pertaining to the flow of foreign portfolio investment in the economy. However, Ahmed and Zlate (2014) and Waqas, Hashmi and Nazir (2015) define foreign portfolio investment volatility as domestic markets' vulnerability to external shocks, particularly in the event of large and sudden fluctuations and risk uncertainty. Furthermore, capital flow volatility is a period of rapid capital inflows that fuel credit booms and asset price inflation, followed by sudden reversals when exchange rates depreciate, equity prices decline and gross domestic product (GDP) growth slows (Caballero \& Krishnamurthy 2006).

This study is also motivated by findings that, because of their nature, capital flows are more volatile and difficult to manage in developing than in advanced economies (Broner \& Rigobon 2004). Developing markets are characterised by the poor quality of financial institutions in economies with weak macroeconomic fundamentals, posing a greater risk of sudden stops or reversal of foreign portfolio flows. Broto et al. (2011) and Karimo and Tobi (2013) conclude that sharp and sudden fluctuations in global portfolio flows pose serious challenges and dilemmas to the developing world even though external funding is required for financial and economic development. Global portfolio investment flows have been observed to be highly unstable and vary considerably across types and time, leading to differences in volatility dynamics (Lo Duca 2012). Furthermore, international financial flows to developing economies have shifted from official to private and from debt to equity financing (Makoni 2014). In developing countries, particularly low-income countries (LICs), foreign portfolio flows are thought to play a destabilising role as they suddenly increase, stop or reverse (Broner 2004; Forbes 2012). In contrast, Alfaro et al. (2007) point out that international investment flows are ideal for financial and economic development as they promote efficient global allocation of financial resources. Based on the foregoing and the threat emanating from global portfolio investment flows as a source of funding, this study seeks to increase understanding of the dynamic behaviour of global portfolio flows to low-income SADC countries in order to assist economic policy-makers and portfolio investors to frame appropriate responses.

Notable cases of the adverse effects of volatile financial flows include the Mexican crisis of 1994-1995, the Asian crisis of 1997-1998 and recently the global financial crisis of 2008-2009 (Ostry 2012). Mercado and Park (2011) stress that short-term financial flows fluctuate significantly and can disrupt the operation of domestic monetary policy and create financial instability that hampers economic growth. Given these threats, investors and economic policy-makers require empirically tested evidence for effective planning and decision-making.

The challenges in managing foreign portfolio flows are a result of the overall surge in the volume of total financial flows and changes in the composition of capital flows as their importance shifts (Becker \& Noone 2008). A major concern is that financial flows can be driven by external shocks that are beyond the control of domestic policies. Consensus that volatility is greater and more difficult to manage in developing than developed economies (see Reinhart \& Rogoff 2009; Rigobon \& Broner 2005) was confirmed during the Asian crisis and the recent global financial crisis. Furthermore, foreign portfolio investment flows were the most volatile component of international capital flows during these crises (Garg \& Dua 2014). Gligoric and Jankovic (2013) also pointed out that portfolio and remittance flows have grown dramatically worldwide, particularly in developing countries where they provide a critical source of foreign currency and external funding.

Despite the surges and reversals in foreign portfolio investment flows to developing economies, there is a dearth of research on the drivers and impact of volatility in net foreign portfolio flows, particularly in LICs. The focus of existing studies is the volatility of gross capital flows (net purchases of domestic assets by foreign agents minus net purchases of foreign assets by domestic agents) with respect to major emerging markets (Broner \& Rigobon 2004; Broto et al. 2011; Forbes \& Warnock 2012; Milesi-Ferretti \& Tille 2011; Neumann et al. 2009). However, even in developing countries, domestic investors are increasingly investing abroad as a way of hedging against capital flow volatility (Bluedorn et al. 2013; Obstfeld 2012).

This study makes several contributions to the literature on the variability of global portfolio investment flows. Firstly, 
the measure of volatility employed is considered superior as it is based on net portfolio flows which reflect changes in an economy's overall current account position. Net foreign portfolio investment flows refer to the difference between net portfolio inflows from international investors buying domestic financial assets, and the net volatility is more powerful and less persistent and has less serial correlation because it is calculated from the absolute values of residuals in line with Broto et al. (2011) and Engle and Rangel (2008), unlike estimates from the rolling window standard deviation or Generalised Autoregressive Conditional Heteroscedasticity (GARCH 1,1) methods. Secondly, this study employs the Panel Autoregressive Distributed Lag (P-ARDL) model, a contemporary panel data analysis approach that can confront and deal with the endogeneity and heterogeneity problems that affected traditional approaches. The study thus informs and advances the current discourse on the causes of capital flow volatility in the field of investment theory and practice.

Thus far, minimal attention has been paid to the short- and long-run predictors of net foreign portfolio investment volatility, particularly in low-income economies. This study seeks to address some of the gaps in the empirical literature on this issue by utilising the Chudik and Pesaran (2013) P-ARDL model.

\section{A brief review of the literature}

Foreign portfolio investment flows refer to cross-border investments in both equity and bond markets (Lo Duca 2012) and are regarded as a critical source of private capital for virtually all economies (Karimo \& Tobi 2013). Developing economies stand to benefit immensely from a constant supply of stable international financial flows. The benefits to recipient economies include increased liquidity in financial markets and the fact that such financial flows are a source of foreign exchange, instil discipline in capital markets, reduce the cost of capital and bridge the savings-investment gap in developing countries (Karimo \& Tobi 2013; Obstfeld \& Rogoff 2009). This study is therefore rooted in the portfolio theory of international capital flows suggested by Devereux and Saito (2006). The theory argues that the national currency composition of national portfolios is critical in determining the direction of flow and mobility of international capital.

However, foreign portfolio investment flows are short term in nature and behave unpredictably, exposing recipient economies to high volatility and vulnerability to global financial crises (Kirabaeva \& Razin 2012; Rothenberg \& Warnock 2006). Excessive portfolio fluctuations increase financial vulnerability and macro-economic instability. Wellinformed policy instruments are thus required to promote macro-financial stability in receiving economies. Broto et al. (2011) note that foreign portfolio investment flows are unstable because they are sensitive to domestic conditions in both developed and developing countries. Similarly, Karimo and Tobi (2013) point out that a stable macro-economic environment is a sound predictor of the variability of foreign portfolio flows in the Nigerian economy. Akçelik et al. (2015) thus recommend an appropriate economic policy mix to address the risks associated with foreign portfolio investment vulnerabilities.

Several factors have been linked to foreign portfolio investment volatility. Mercado and Park (2011) found that trade openness significantly drives the volatility of global portfolio flows, whilst an increase in market capitalisation, global liquidity growth and high institutional quality lowers the variability of such flows. Broner and Rigobon (2004) found less convincing evidence on the impact of inflation on portfolio flows but concluded that economic development is a good predictor. On the other hand, Rai and Bhanumurthy (2004) observed that higher domestic inflation pushes returns upwards, inducing international investors to buy more domestic assets and hence exhibiting a positive relationship. This study therefore employs the macro-financial variables affecting low-income economies to explain the variability of foreign portfolio flows.

According to Lo Duca (2012), foreign portfolio flows are subject to informational problems and rational herding behaviour in financial markets as investors seek international diversification opportunities (also see Calvo \& Mendoza 2000). A major source of instability that is inherent in foreign portfolio flows arises from the trading activities of fund managers when they enter and leave the market at the same time (Haley 2001). Foreign portfolio stocks and bonds have been observed to be highly liquid, enabling investors to dispose of their assets quickly (Lo Duca 2012). Lo Duca (2012) also highlights that the drivers of capital flows vary across time and cross-sectional units, complicating their estimation. In addition, capital controls have an insignificant effect on the stability of foreign portfolio investment flows (Alfaro et al. 2007; Lo Duca 2012).

Furthermore, variability in exchange rates and a decline in returns as well as high inflation considerably increase the instability of foreign portfolio flows (Çulha 2006; Kodongo \& Ojah 2012; Waqas et al. 2015). Choong et al. (2010) stress that the relationship between stock markets and global portfolio flows relies heavily on the level of stock market development. On the other hand, Carrieri, Errunza and Majerbi (2006) argue that the focus should be on real exchange rate fluctuations as opposed to nominal exchange rate volatility because the real exchange rate eliminates inflation and is a superior indicator of net foreign portfolio investment volatility. Empirical evidence also shows that there is an inverse relationship between exchange rate and portfolio flows (Bleaney \& Greenaway 2001; Ersoy 2013; Waqas et al. 2015).

Based on the theory of portfolio investment, foreign investors are attracted by high interest rates as they reduce borrowing costs and the foreign investor will invest until interest rates are equalised across the world. However, this theory becomes problematic when risk, uncertainty and volatility are introduced (Waqas et al. 2015). In terms of high volatility, investors prefer to go short term, but as the environment 
becomes uncertain they withdraw their investment (Kodongo \& Ojah 2012). On the other hand, stock market performance attracts capital flows and tends to stabilise portfolio flows, thereby attracting interest from both domestic and international investors as well as economic policymakers (Ferreira \& Laux 2009; Karimo \& Tobi 2013). At micro-economic level, the effects of portfolio flows on financially constrained firms' access to finance exceed the negative effects of volatility in portfolio flows (Knill \& Lee 2014), and they remain beneficial even during crisis periods (Beck, Demirgüç-Kunt \& Levine 2009).

Neumann et al. (2009) and Daude and Fratzscher (2008) concluded that high industrial productivity stabilises the variability of foreign portfolio flows. This is evident in advanced economies with high and stable output production. However, Mody, Taylor and Kim (2001) obtained mixed results regarding this relationship, whilst De Vita and Kyaw (2008) suggest that output and industrial production are important pull factors in explaining foreign portfolio investment volatility.

Finally, a positive association has been identified between foreign direct investment (FDI) and foreign portfolio investment volatility, as an increase in FDI boosts market confidence and attracts stable foreign portfolio flows (Gözgör \& Erzurumlu 2010; Waqas et al. 2015). However, Levchenko and Mauro (2007) indicate that during crisis periods, foreign portfolio investment is neither consistent nor persistent compared to other capital flows. Moreover, Ferreira and Laux (2009) observed that foreign portfolio investment volatility is positively related to financial liberalisation.

Whilst several approaches have been identified to measure historical volatility, the estimation process is not straightforward (Broto et al. 2011; Neumann et al. 2009). These approaches include GARCH $(1,1)$, rolling window standard deviation, exponential weighted moving average (EWMA) and the Spline-GARCH model. Broto et al. (2011) concluded that the residuals derived from the panel model approach produced superior results to the GARCH $(1,1)$ and the rolling window standard deviation methods because of its robust nature. Therefore, in line with Salisu and Isah (2017) and Broto et al. (2011), the reduced form volatility estimation is given below:

$V_{c t}^{2}=\frac{1}{4} \sum_{j=1}^{4}\left|R_{c t j}\right|$

[Eqn 1]

where $j$ represents each quarter of year $t$ and $R_{c t j}$ is the annual average of the absolute value of quarterly residuals.

Traditional approaches such as the rolling window method are not suitable for this study as they lose observations at the beginning of the sample. Moreover, volatility is highly persistent as it depends on previous periods, leading to problems of endogeneity and serial correlation (Broto et al. 2011). In addition, these approaches give the same weight to recent and previous flows, thereby normalising the volatility dynamics and leading to volatility underestimation during a shock and overestimation thereafter. Finally, the EWMA is a symmetrical model where large negative capital flows have the same impact as large positive ones. Hence, it merely smooths the squared time series and fails to capture capital flow volatility dynamics.

Based on Broto et al. (2011), the residuals approach offers long horizon forecasts of volatility which depend on economic fundamentals and deliver the volatility estimates anticipated in a newly opened market.

According to Broto et al. (2011), the absolute values of residuals are produced by an autoregressive integrated moving average (ARIMA) model as developed by Caporello and Maravall (2003). A suitable ARIMA model is estimated for each country and type of capital flow on a quarterly basis. In this study, the absolute values of residuals are generated using the EViews program in line with Schwert (2015). This program was used because of its ability to create a new series from an existing one (i.e., lag values). In this study, a new series is established from the one period lag values of the original series (AR1 process), making it possible to estimate the regressions and generate the absolute values of the residual values.

In summary, the literature seems to suggest that there is a lack of consensus on the key factors driving foreign portfolio investment volatility. The empirical literature cites a number of reasons for this, including differences in samples or data used, different research methods and the time varying behaviour of the drivers of volatility because of changes in investors' tastes and preferences (Alfaro, Kalemli-Ozcan \& Volosovych 2004; Lo Duca 2012). The next section discusses the methods used in this study.

\section{Data sources and research methodology}

\section{Data sources}

The study utilises quarterly unbalanced panel data spanning a period of 16 years from 2000:Q1 to 2015:Q4. The choice of the study period and the cut-off dates were influenced by the availability of data on foreign portfolio investment flows in low-income SADC countries. The main data sources are the World Bank Data Bank, the International Monetary Fund's (IMF) International Financial Statistics, Bloomberg and the central statistical centres of the respective countries' central banks. Based on the World Bank data (July 2014), the selected countries are Zimbabwe, Zambia, Malawi, Lesotho, Madagascar, Mozambique, DRC, Swaziland and Tanzania.

\section{Estimating net foreign portfolio investment volatility}

An important part of the data used in this study is the determination of net foreign portfolio volatility estimates for net portfolio flows for each individual LIC. The study 
employs the absolute values of residuals as guided by Engle and Rangel (2008) and successfully utilised by Broto et al. (2011). This approach produces superior results compared to the traditional GARCH $(1,1)$ and the rolling window standard deviation method. According to Broto et al. (2011), the absolute values of residuals are produced from an ARIMA model calculated by the automatic procedure of TRAMOSEATS for Windows (TSW) developed by Caporello and Maravall (2003) of the Bank of Spain. However, in this study, the absolute values of residuals are produced using the EViews program as demonstrated by Professor G.W. Schwert (2015). EViews' ability to create a new series from an existing one (i.e. lag values) makes it ideal. A new series is established from the one period lagged values of the original series (AR1 process), making it possible to estimate the regressions and generate the absolute values of residual values.

After generating the absolute values of residuals, the quarterly variance of net foreign investment flows is estimated from the quarterly averages of the absolute values of monthly residuals $\left(R_{c t}\right)$. As stated in the literature review and based on Broto et al. (2011), the reduced form volatility estimation equation is as follows:

$v_{c t}^{2}=\frac{1}{4} \sum_{j=1}^{4}\left|R_{c t j}\right|$

[Eqn 2]

where $j$ represents each quarter of year $t$ and $R_{c t j}$ is the annual average of the absolute value of quarterly residuals.

According to Broto et al. (2011), the residuals approach offers robust estimates of historical volatility relative to the values generated by GARCH $(1,1)$ and rolling window standard deviation. The residuals approach also allows for long-term forecasts of volatility to be based on economic fundamentals and delivers the variability estimates anticipated in a recently liberalised economy.

\section{Estimation technique}

The objective of this study is to ascertain and explain the main predictors of foreign portfolio investment volatility in low-income SADC countries. It follows Rafindadi and Yosuf (2013), Hegerty (2011), Al Mamun, Sohog and Akhter (2013) and Mohaddes and Raissi (2014) in utilising Chudik and Pesaran's P-ARDL model (2013). The choice of this model was driven by several advantages it has over conventional short- and long-run estimation techniques.

The P-ARDL model is chosen primarily because of its flexibility with small sample studies. This approach accommodates variables that are of different order of integration, that is, it can handle $\mathrm{I}(0)$ and $\mathrm{I}(1)$ variables but not I(2). According to Giles (2013), ARDL is a contemporary technique for investigating long- and short-run dynamics. In addition, the P-ARDL model enables different variables to be assigned different lags in the same system (Giles 2013; Hegerty 2011). Furthermore, it is simple to set-up, implement and interpret as it involves a single equation, but at the same time powerful enough to accommodate more than two lags and six variables (Giles 2013; Oluseye \& Gabriel 2017). Moreover, the Chudik and Pesaran (2013) P-ARDL model is ideal for panel analysis as it accounts for cross-sectional dependency (CSD) and allows for one or two structural breaks when carrying out unit root tests. Finally, it is powerful in estimating the long- and short-run parameters of the model (Dritsakis 2011; Shin et al. 2014).

Now suppose that the P-ARDL regression model for lowincome SADC countries is given by:

$$
\begin{aligned}
\Delta Y_{i t}= & \delta_{i 0}+\delta_{1} \Delta X_{i t-1}+\delta_{2} \Delta X_{i t-2}+\delta_{3} \Delta X_{i t-3}+\ldots \ldots \\
& +\delta_{p} \Delta X_{i t-p}+\omega_{1} y_{i t-1}+\omega_{2} y_{i t-2}+\omega_{3} y_{i t-3}+\ldots \ldots \\
& +\omega_{q} y_{i t-q}+\varepsilon_{i t}
\end{aligned}
$$

where $Y_{i t}$ is a vector of $(\mathrm{kx} 1)$ vector representing net foreign portfolio investment volatility, $i$ represents the low-income SADC countries, $\Delta$ captures first difference operator, $X_{i}$ and $y_{i}$ are the lagged independent variables for every $i=1$ $\ldots \ldots \ldots \ldots \ldots . . . . . p$ and $q, \delta_{1}-\delta_{p}$ denote the short-run co-efficiency of the model explaining short-run relationships, $\omega_{1}-\omega_{q}$ correspond to the long-run relationship and $e_{i t}$ represents the vector of noise term.

\section{Ethical consideration}

This article followed all ethical standards for a research without direct contact with human or animal subjects.

\section{Empirical analysis and interpretation of results}

This section begins the empirical analysis of the methodology employed and the interpretation of results using P-ARDL. The aim is to establish the main drivers of net foreign portfolio investment volatility in low-income SADC countries. The role of foreign portfolio investment flows in financing stagnant economies and large budget deficits in developing countries cannot be ignored. Furthermore, it is important to note that net foreign portfolio investment flows into lowincome SADC countries will assist in equilibrating overall savings and investment in the region (Friedman 1986) in order to stimulate economic growth. In line with Al Mamun et al. (2013), Rafindadi and Yosuf (2013) and Gerni et al.'s (2013) empirical studies, we adopt Chudik and Pesaran's (2013) P-ARDL model using quarterly data spanning 16 years from 2000 to 2015. Based on Kutu and Ngalawa (2016), the P-ARDL model is ideal for this study because it accounts for CSD, accommodates one or two structural breaks when conducting unit root tests and is suitable for panel analysis (Chudik \& Pesaran 2013).

\section{Panel Autoregressive Distributed Lag unit root results}

The study tests for the presence of unit roots to determine the stationarity of the data set using the Levin, Lin and 
Chu (LLC), Im, Pesaran and Shin (IPS) and Augmented Dickey-Fuller (ADF) tests at individual intercept and individual intercept and trend. All three methods of unit root testing are used so as to compare and validate the results, thereby ensuring consistency. This is in line with Moon and Perron (2004), Demetriades and Fielding (2012) and Ishibashi (2012). At 5\% significance level for the benchmark, the findings show that after first differencing, all the variables in the model are stationary at order one, that is, I (1). Whilst the LLC unit root test shows that inflation (CPI), world output (WGDP) and international interest rates (FFR) are not stationary at I(1), both the IPS and ADF results show otherwise and indicate that these variables are stationary at $\mathrm{I}(1)$. This is a majority result that is hence adopted for the study. Furthermore, the unit root test results are consistent with Kutu and Ngalawa (2016). This satisfies Sari, Ewing and Soytas (2008) and Katircioglu's (2009) conditions for running an ARDL model. According to these scholars, ARDL can be used with a mixture of $\mathrm{I}(0)$ and $\mathrm{I}(1)$ variables as well as fractionally integrated order or irrespective of their order of integration. This means that this approach can be applied to data or variables whether they are only $\mathrm{I}(0), \mathrm{I}(1)$, a mixture of $\mathrm{I}(0)$ and $\mathrm{I}(1)$, mutually co-integrated or regardless of their order of integration but not I(2). Furthermore, Pesaran, Shin and Smith (2001) point out that the dependent variable must be I(1). As shown in Table 1, the dependent variable is I(1) and hence, satisfies the Pesaran et al. (2001) condition for running an ARDL model.

\section{The test for cross-sectional dependency}

Notwithstanding the postulation that the Chudik and Pesaran (2013) P-ARDL model accounts for CSD, and the alternative standard augmented Dickey-Fuller (ADF) test proposed by Pesaran (2007) to remove the impact of CSD, the study first conducts a chow test to ascertain whether the data for the SADC countries can be pooled. The findings are supportive of pooled regression for these countries. Thereafter, the Pesaran cross-sectional dependence (Pesaran $\mathrm{CD}$ ) test is used to test whether the error term or residuals are correlated across units. The benchmark hypotheses that are tested for CSD are as follows:

- $H 0: \beta=1$, there is no correlation of the residuals (error term).

- $H 1: \beta \neq 1$, there is correlation of the residuals (error term).

The results show a $t$-statistic value of 21.791 is greater than the Pesaran table value at $5 \%$; hence, the study fails to reject the null hypothesis of no correlation of the residuals but rejects the alternative hypothesis that correlation of the residuals exists in the model. Accordingly, the Pesaran CD test conducted on the P-ARDL regression model does not show the presence of CSD or common factors affecting the cross-sectional units
TABLE 1a: Levin, Lin and Chu, Im, Pesaran and Shin and Augmented DickeyFuller unit root tests.

\begin{tabular}{|c|c|c|c|c|c|c|}
\hline \multirow[t]{2}{*}{ Variables } & \multicolumn{3}{|c|}{$\begin{array}{l}\text { Levin, Lin and Chu } \\
\text { (individual intercept) }\end{array}$} & \multicolumn{3}{|c|}{$\begin{array}{l}\text { Levin, Lin and Chu (individual } \\
\text { intercept and trend) }\end{array}$} \\
\hline & $\begin{array}{l}\text { Order of } \\
\text { integration }\end{array}$ & $t^{*}$ statistics & $p$ & $\begin{array}{l}\text { Order of } \\
\text { integration }\end{array}$ & $t^{*}$ statistics & $p$ \\
\hline $\mathrm{CPI}$ & I(1) & 4.656 & 1.000 & $\mathrm{I}(1)$ & 6.451 & 1.000 \\
\hline FFR & $\mathrm{I}(1)$ & 2.279 & 0.989 & $\mathrm{I}(1)$ & 4.022 & 1.000 \\
\hline M2 & $\mathrm{I}(1)$ & -1.648 & $0.050 * *$ & $I(1)$ & 0.259 & 0.602 \\
\hline RGDP & $\mathrm{I}(1)$ & -1.771 & $0.038 * *$ & $\mathrm{I}(1)$ & -0.299 & 0.382 \\
\hline INT & $\mathrm{I}(1)$ & -2.269 & $0.012 * * *$ & $\mathrm{I}(1)$ & -0.9799 & 0.164 \\
\hline NFPI & $\mathrm{I}(1)$ & -11.85 & $0.000 * * *$ & $\mathrm{I}(1)$ & -10.977 & $0.000 * * *$ \\
\hline WGDP & I(1) & 17.178 & 1.000 & I(1) & 24.158 & 1.000 \\
\hline
\end{tabular}

$\mathrm{CPI}$, inflation; FFR, international interest rate; $\mathrm{M} 2$, money supply; RGDP, real gross domestic product; INT, domestic interest rate; NFPI, net foreign portfolio investment; WGDP, world output; IPS, Im, Pesaran and Shin; ADF, augmented Dickey-Fuller.

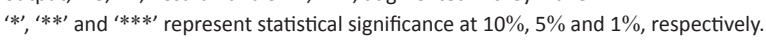

TABLE 1b: Levin, Lin and Chu, Im, Pesaran and Shin and Augmented DickeyFuller unit root tests.

\begin{tabular}{|c|c|c|c|c|c|c|}
\hline \multirow[t]{2}{*}{ Variables } & \multicolumn{3}{|c|}{$\begin{array}{l}\text { IPS unit-root test } \\
\text { (individual intercept) }\end{array}$} & \multicolumn{3}{|c|}{$\begin{array}{l}\text { IPS unit-root test } \\
\text { (individual intercept and trend) }\end{array}$} \\
\hline & $\begin{array}{l}\text { Order of } \\
\text { integration }\end{array}$ & $\begin{array}{c}t^{*} \\
\text { statistics }\end{array}$ & $p$ & $\begin{array}{l}\text { Order of } \\
\text { integration }\end{array}$ & $\begin{array}{c}t^{*} \\
\text { statistics }\end{array}$ & $p$ \\
\hline $\mathrm{CPI}$ & $\mathrm{I}(1)$ & -5.710 & $0.000 * * *$ & $\mathrm{I}(1)$ & -5.197 & $0.000 * * *$ \\
\hline FFR & $\mathrm{I}(1)$ & -4.662 & $0.000 * * *$ & $\mathrm{I}(1)$ & -2.738 & $0.003 * * *$ \\
\hline M2 & $\mathrm{I}(1)$ & -7.425 & $0.000 * * *$ & $\mathrm{I}(1)$ & -6.295 & $0.000 * * *$ \\
\hline RGDP & $\mathrm{I}(1)$ & -7.702 & $0.000 * * *$ & $\mathrm{I}(1)$ & -6.478 & $0.000 * * *$ \\
\hline INT & $\mathrm{I}(1)$ & -5.937 & $0.000 * * *$ & $I(1)$ & -4.333 & $0.000 * * *$ \\
\hline NFPI & $\mathrm{I}(1)$ & -16.206 & $0.000 * * *$ & $\mathrm{I}(1)$ & -15.624 & $0.000 * * *$ \\
\hline WGDP & $\mathrm{I}(1)$ & -19.029 & $0.000 * * *$ & $\mathrm{I}(1)$ & -18.303 & $0.000 * * *$ \\
\hline
\end{tabular}

$\mathrm{CPI}$, inflation; FFR, international interest rate; $\mathrm{M} 2$, money supply; RGDP, real gross domestic product; INT, domestic interest rate; NFPI, net foreign portfolio investment; WGDP, world output; IPS, Im, Pesaran and Shin; ADF, augmented Dickey-Fuller.

${ }^{\prime \prime},{ }^{\prime * * \prime}$ and ${ }^{\prime * * * \prime}$ represent statistical significance at $10 \%, 5 \%$ and $1 \%$, respectively.

TABLE 1c: Levin, Lin and Chu, Im, Pesaran and Shin and Augmented DickeyFuller unit root tests.

\begin{tabular}{|c|c|c|c|c|c|c|}
\hline \multirow[t]{2}{*}{ Variables } & \multicolumn{3}{|c|}{$\begin{array}{c}\text { ADF-Fisher Chi-square unit } \\
\text { root-test } \\
\text { (individual intercept) }\end{array}$} & \multicolumn{3}{|c|}{$\begin{array}{l}\text { ADF-Fisher Chi-square unit } \\
\text { root-test (individual intercept } \\
\text { and trend) }\end{array}$} \\
\hline & $\begin{array}{l}\text { Order of } \\
\text { integration }\end{array}$ & $\begin{array}{c}t^{*} \\
\text { statistics }\end{array}$ & $p$ & $\begin{array}{l}\text { Order of } \\
\text { integration }\end{array}$ & $\begin{array}{c}t^{*} \\
\text { statistics }\end{array}$ & $p$ \\
\hline $\mathrm{CPI}$ & I(1) & 74.371 & $0.000 * * *$ & $\mathrm{I}(1)$ & 64.078 & $0.000 * * *$ \\
\hline FFR & $\mathrm{I}(1)$ & 52.253 & $0.000 * * *$ & $\mathrm{I}(1)$ & 31.269 & $0.027 * *$ \\
\hline M2 & $\mathrm{I}(1)$ & 90.970 & $0.000 * * *$ & $\mathrm{I}(1)$ & 70.232 & $0.004 * * *$ \\
\hline RGDP & $\mathrm{I}(1)$ & 97.404 & $0.000 * * *$ & $\mathrm{I}(1)$ & 74.075 & $0.000 * * *$ \\
\hline INT & I(1) & 75.600 & $0.000 * * *$ & $\mathrm{I}(1)$ & 54.777 & $0.000 * * *$ \\
\hline NFPI & I(1) & 246.136 & $0.000 * * *$ & $\mathrm{I}(1)$ & 212.052 & $0.000 * * *$ \\
\hline WGDP & $\mathrm{I}(1)$ & 297.230 & $0.0000 * *$ & $\mathrm{I}(1)$ & 254.503 & $0.000 * * *$ \\
\hline
\end{tabular}

$\mathrm{CPI}$, inflation; FFR, international interest rate; $\mathrm{M} 2$, money supply; RGDP, real gross domestic product; INT, domestic interest rate; NFPI, net foreign portfolio investment; WGDP, world output; IPS, Im, Pesaran and Shin; ADF, augmented Dickey-Fuller.

'*', '**' and ${ }^{\prime * * * \prime}$ represent statistical significance at $10 \%, 5 \%$ and $1 \%$, respectively.

in the SADC countries. This is similar to Pesaran (2007) and Gow, Ormazabal and Taylor (2010) who corrected for CSD in their respective studies.

\section{The Panel Autoregressive Distributed Lag determination}

To ensure robust and efficient results, this study utilises the unrestricted likelihood ratio test for the lag lengths and conducts various lag selection criteria to determine the optimum lag for the P-ARDL model. The various orders of lags conducted for the model are the sequential modified likelihood-ratio test statistic (LR), final prediction error (FPE), Akaike information criterion (AIC), Schwarz 
Bayesian information criterion (SBIC) and Hannan-Quinn information criterion (HQIC). The P-ARDL is conducted for eight (8) lags order. The results in Table 3 show that the SBIC selects lag two (2), whilst the LR, FPE, AIC and HQIC select lag three (3). The benchmark hypothesis for choosing the optimum lag is to select the lag that gives the minimum criteria. As presented below, lag 3 gives the minimum criteria for the value of the LR, FPE, AIC and HQIC which is now the optimal lag length for the variables in the system. Therefore, lag 3 is chosen for the P-ARDL model; this is consistent with Olarewaju, Sibanda and Migiro (2017) and Nowak-Lehmann et al. (2011). The choice of lag 3 allows the model to be dynamic and robust and prevents shortening of the data set. This is in line with the order of lags selected by Ali, Irum and Ali (2008) and Raza, Shahbaz and Nguyen (2015).

\section{Determining the strength of the model selection criteria}

As indicated in Table 2 where the LR, FPE, AIC and HQIC select lag three (3), the AIC gives the smallest number amongst them. The benchmark hypothesis is that the smaller the number, the better the model for selecting optimal lag length. In order to determine the strength of the AIC over other criteria (LR, FPE and HQIC) that chose 3 lag for model selection in the regression, this study employs the criteria graph to determine the top 16 different P-ARDL models based on the benchmark analysis that the lower the value of the criteria, the better the model. The ARDL $(4,4,4,4,4,4,4)$ model seems to be superior to the others.

\section{The Panel Autoregressive Distributed Lag model}

In the estimation of the main predictors of net foreign portfolio investment flows in low-income SADC economies, the results from the P-ARDL show that in the long run, all the variables in the model are statistically significant in explaining net foreign portfolio investment volatility in SADC countries (see Table 3). In particular, the findings reveal that world GDP, real GDP, money supply (M2) and prices (CPI) have a positive long-run impact on net foreign portfolio investment volatility in these economies, whilst global interest rates (FFR) and domestic interest rates (INT) have a negative impact on net foreign portfolio investment flows in the low-income SADC countries. The reason is that as world GDP grows, foreign investors may sometimes invest in other countries' stock and bond markets for speculation and in an attempt to diversify and expand their horizons. This relationship is consistent with economic theory (an increase in money supply will have a positive impact whilst an increase in interest rates will have a negative impact) and empirical evidence such as that provided by Kolodko (2006). The positive relationship amongst world GDP, real GDP, money supply and prices is an indication that an increase in these variables will lead to an increase in net foreign portfolio investment volatility in SADC countries.
TABLE 2: Lag length determination and selection for the Panel Autoregressive Distributed Lag model.

\begin{tabular}{lcccccc}
\hline Lag & LogL & LR & FPE & AIC & SBIC & HQIC \\
\hline 0 & -2543.125 & NA & $7.04 \mathrm{e}-05$ & 10.304 & 10.363 & 10.327 \\
1 & -1026.793 & 2983.651 & 1.874 & 4.375 & 4.851 & 4.562 \\
2 & -833.634 & 374.612 & 1.052 & 3.793 & $4.684^{*}$ & 4.143 \\
3 & -31.623 & $283.289^{*}$ & $1.358^{*}$ & $1.740^{*}$ & 5.129 & $3.070^{*}$ \\
4 & -788.470 & 86.313 & 1.067 & 3.808 & 5.116 & 4.322 \\
5 & -613.947 & 328.597 & 6.411 & 3.301 & 5.025 & 3.978 \\
6 & -472.825 & 261.718 & 4.421 & 2.929 & 5.069 & 3.769 \\
7 & -292.631 & 329.082 & 2.601 & 2.399 & 4.955 & 3.402 \\
8 & -191.702 & 181.469 & 2.121 & 2.189 & 5.162 & 3.356 \\
\hline
\end{tabular}

LR, likelihood-ratio; FPE, final prediction error; AIC, Akaike information criterion; SBIC Schwarz Bayesian information criterion; HQIC, Hannan-Quinn information criterion.

'*', ‘*’ and '***' represent statistical significance at $10 \%$.

TABLE 3: The Panel Autoregressive Distributed Lag regression model.

\begin{tabular}{|c|c|c|c|c|}
\hline Variable & Coefficient & Std. error & $t$-statistic & Prob.* \\
\hline \multicolumn{5}{|l|}{ Long run equation } \\
\hline LOGFFR & -0.043 & 0.049 & -0.872 & 0.014 \\
\hline LOGWGDP & 1.641 & 1.042 & 1.575 & 0.009 \\
\hline LOGRGDP & 0.312 & 0.031 & 10.014 & 0.000 \\
\hline LOGM2 & 0.360 & 0.240 & 1.494 & 0.027 \\
\hline LOGCPI & 0.008 & 0.010 & 0.777 & 0.063 \\
\hline INT & -0.000 & 0.000 & -2.117 & 0.003 \\
\hline \multicolumn{5}{|l|}{ Short run equation } \\
\hline COINTEQ01 & -0.090 & 0.130 & -9.918 & 0.000 \\
\hline D(LOGNFPI(-1)) & 0.178 & 0.119 & 1.488 & 0.038 \\
\hline $\mathrm{D}($ LOGNFPI(-2)) & -0.107 & 0.081 & -1.332 & 0.014 \\
\hline D(LOGNFPI(-3)) & -0.241 & 0.096 & -2.511 & 0.013 \\
\hline $\mathrm{D}($ LOGFFR) & 0.042 & 0.123 & 0.342 & 0.033 \\
\hline $\mathrm{D}($ LOGFFR(-1)) & -0.017 & 0.078 & -0.216 & 0.029 \\
\hline $\mathrm{D}($ LOGFFR(-2)) & 0.270 & 0.088 & 3.068 & 0.002 \\
\hline $\mathrm{D}($ LOGWGDP) & -1.230 & 2.459 & -0.500 & 0.017 \\
\hline D(LOGWGDP(-1)) & -4.658 & 2.213 & -2.105 & 0.036 \\
\hline D(LOGWGDP(-2)) & -9.220 & 1.992 & -4.629 & 0.000 \\
\hline $\mathrm{D}($ LOGRGDP) & 0.636 & 0.275 & 2.318 & 0.021 \\
\hline $\mathrm{D}(\operatorname{LOGRGDP}(-1))$ & 0.024 & 0.199 & 0.122 & 0.003 \\
\hline $\mathrm{D}($ LOGRGDP(-2)) & 0.762 & 1.017 & 0.749 & 0.054 \\
\hline D(LOGM2) & 0.336 & 0.823 & 0.408 & 0.003 \\
\hline $\mathrm{D}(\operatorname{LOGM} 2(-1))$ & 0.771 & 0.952 & 0.809 & 0.019 \\
\hline $\mathrm{D}($ LOGM2(-2)) & 2.569 & 1.408 & 1.824 & 0.069 \\
\hline $\mathrm{D}($ LOGCPI) & 1.628 & 1.864 & 0.873 & 0.033 \\
\hline $\mathrm{D}($ LOGCPI(-1)) & 3.926 & 2.279 & 1.722 & 0.006 \\
\hline $\mathrm{D}($ LOGCPI(-2)) & 2.632 & 1.992 & 1.321 & 0.017 \\
\hline $\mathrm{D}(\mathrm{INT})$ & -0.026 & 0.012 & -2.199 & 0.029 \\
\hline $\mathrm{D}(\mathrm{INT}(-1))$ & 0.033 & 0.018 & 1.771 & 0.078 \\
\hline $\mathrm{D}(\mathrm{INT}(-2))$ & -0.005 & 0.006 & -0.889 & 0.075 \\
\hline C & 0.002 & 0.016 & 0.099 & 0.021 \\
\hline
\end{tabular}

ARDL, autoregressive distributed lag.

Dependent variable: D(DLOGNFPI); Method: ARDL; Sample: 2001Q2 2015Q4; Model selection method: Akaike info criterion (AIC); Selected model: $\operatorname{ARDL}(4,3,3,3,3,3,3)$.

Conversely, interest rates have a negative impact on net foreign portfolio investment flows in the low-income SADC countries. This can be inferred to mean that a contractionary policy has an adverse effect on net foreign portfolio investment in these countries. This relationship is supportive of economic theory and Neumeyer and Perri's (2005) empirical evidence.

As far as the short run is concerned, the coefficients of all the explanatory variables were found to be statistically significant; hence, indicating that at $5 \%$ and $10 \%$, all the 
variables in the model serve as the main predictors of net foreign portfolio investment flow volatility in SADC countries. The results demonstrate that, in the short run, all

\begin{tabular}{lccc}
\hline F-statistic & 1.230 & Prob. $F(11,022)$ & 0.306 \\
Obs* $R$-squared & 13.352 & Prob. Chi-Square (12) & 0.311 \\
\hline
\end{tabular}

'*', '**'and ${ }^{\prime * * * \prime}$ represent statistical significance at $10 \%, 5 \%$ and $1 \%$, and, respectively. FIGURE 1: Heteroscedasticity test: Breusch-Pagan-Godfrey.

\begin{tabular}{|lccc|}
\hline$F$-statistic & 1.283 & Prob. $F(2,220)$ & 0.121 \\
Obs* $R$-squared & 2.069 & Prob. Chi-square (2) & 0.125 \\
\hline
\end{tabular}

'*', ‘**'and ${ }^{\prime * * * \prime}$ represent statistical significance at $10 \%, 5 \%$ and $1 \%$, respectively. FIGURE 2: Breusch-Godfrey serial correlation LM test.

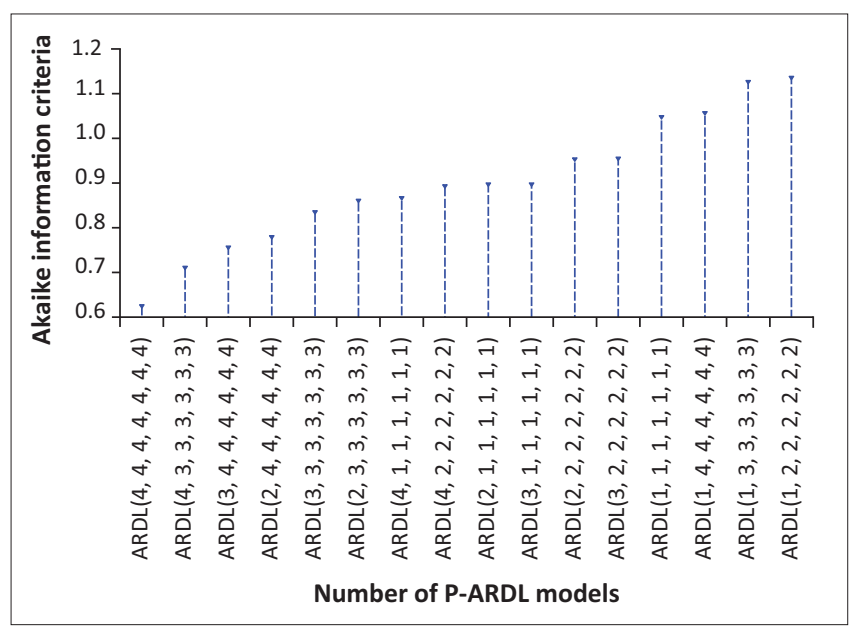

FIGURE 3: Possible number of panel ARDL (autoregressive distributed lag) models using the Akaike Information Criteria. the variables are major drivers of net foreign portfolio investment volatility in these LICs.

\section{Diagnostic and reliability tests}

In order to determine the reliability of the P-ARDL model, the study tests for heteroscedasticity, serial correlation and stability of the model. The benchmark null hypotheses tested for the model are as follows:

- $H 0: \beta=1$, there is no heteroscedasticity and serial correlation in the model.

- $H 1: \beta \neq 1$, there is heteroscedasticity and serial correlation in the model.

The results in Figure 1 and 2 show that there is no heteroscedasticity and serial correlation in the model. Figure 3 shows possible number of panel ARDL models using the Akaike Information Criteria. The probability values in the two tables confirm the model to be free from heteroscedasticity and serial correlation. The stability graph also shows the stability test of the model. The line capturing the study's data passes within the $5 \%$ confidence interval; hence, the model is stable. Therefore, the null hypothesis of stability is accepted for the model.

Figure 4 shows that the CUSUM statistics are well within the critical bounds, signifying the stability of all the coefficients in the error correction model. This finding is in line with Halicioglu (2005) and shows that there is a stable long-run relationship between the dependent and independent variables in the model.

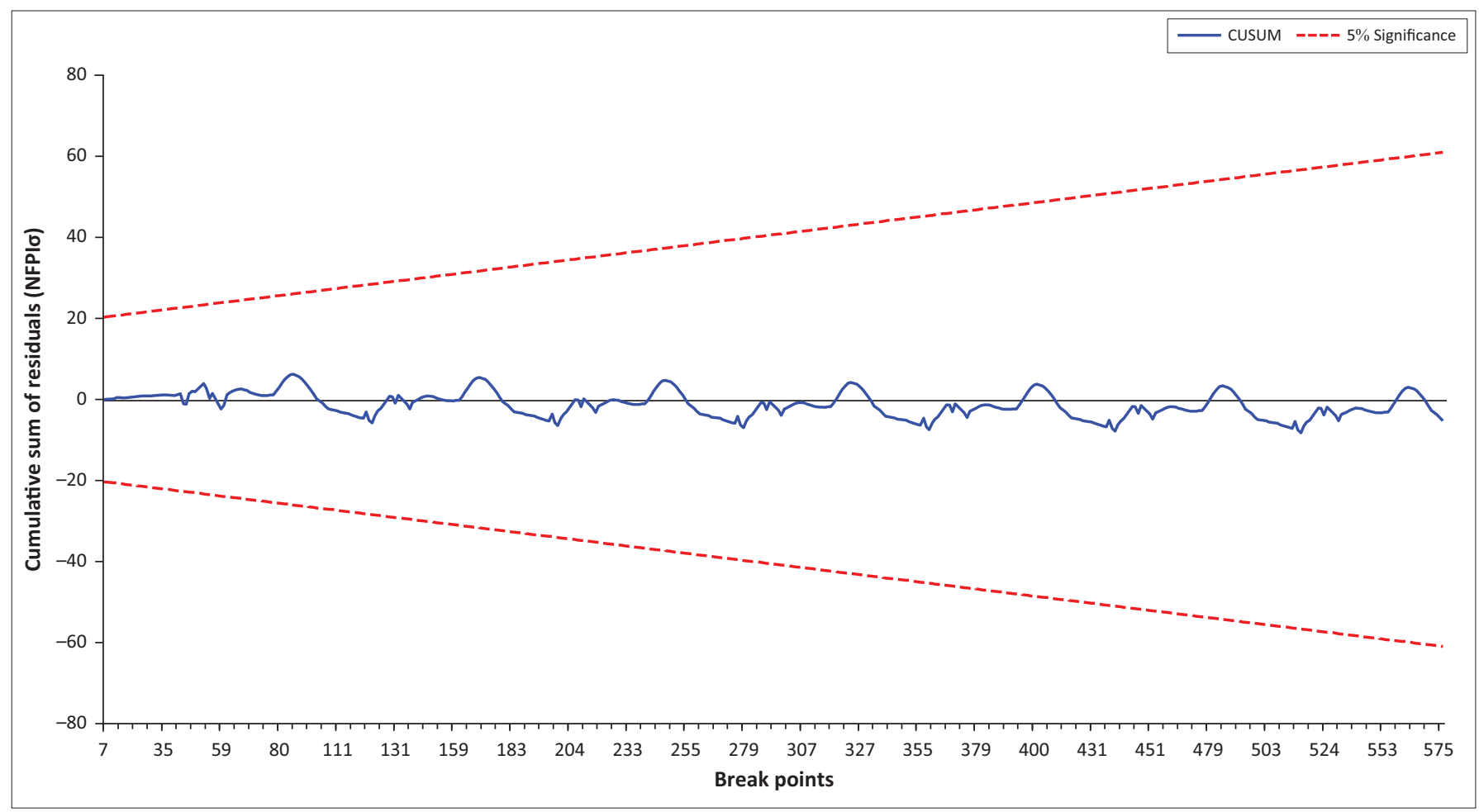

CUSUM, cumulative sum of recursive residuals; NFPIo, net foreign portfolio investment.

FIGURE 4: Stability test for the autoregressive distributed lag model. 
TABLE 4: The Panel Autoregressive Distributed Lag co-integration test (Wald test).

\begin{tabular}{lccc}
\hline Test statistic & Value & Degree of freedom & Probability \\
\hline F-statistic & 5.219 & $(2,227)$ & 0.006 \\
Chi-square & 10.439 & 2 & 0.005 \\
\hline
\end{tabular}

ARDL, autoregressive distributed lag.

TABLE 5: The Panel Autoregressive Distributed Lag error correction term.

\begin{tabular}{lcccc}
\hline Variable & Coefficient & Std. error & $t$-statistic & Prob. \\
\hline ECT & -0.733 & 0.117 & 6.239 & 0.000 \\
\hline
\end{tabular}

$\mathrm{ECT}$, error correction term

\section{The Panel Autoregressive Distributed Lag co-integration results}

The default parameter estimate of the short-run coefficient (COINTEQ01) with the coefficient value of -0.090 and probability value of 0.000 is an indication of disequilibrium in the past that can be corrected in the future. The negative coefficient means disequilibrium, whilst its significant probability value confirms the possibility of reverting to equilibrium in the long run with a high speed of adjustment. This is as expected and indicates the existence of long-run co-integration amongst the variables (otherwise there would be no co-integration). Furthermore, a P-ARDL cointegration test is conducted to validate the model and the result. As shown in Table 4 below, the $F$-statistics show a $p$-value of less than 0.05 . Therefore, the study rejects the null hypothesis of no co-integration and fails to reject the alternative hypothesis that there is a long-run cointegration relationship amongst the variables in the model. The $F$-statistic value of 5.219 is greater than the upper band of the Pesaran critical value of 3.01 at 5\% level (Pesaran \& Pesaran 1997:478). This again shows evidence of a long-run co-integration relationship amongst net foreign portfolio investment volatility and the other variables in the model.

\section{The Panel Autoregressive Distributed Lag error correction term}

In further validating the existence of long-run equilibrium that was revealed in the Diagnostic and reliability tests section, Table 5 shows the results of the error correction term (ECT). The negative sign of the ECT coefficient shows the existence of disequilibrium in the short run and convergence of the system in the long run. The ECT value of -0.733 suggests a relatively high speed of adjustment from shortrun disequilibrium to the restoration of equilibrium in the long run of net foreign portfolio investment volatility. This is in line with the results revealed by the default parameter of (COINTEQO1) as shown in Table 3. These results are consistent with Waliullah and Rabbi (2011) and Banerjee, Dolado and Mestre (1998) on the existence of a stable longrun relationship.

\section{Conclusions}

This study examined the main predictors of net foreign portfolio investment volatility in low-income SADC countries using a P-ARDL model with quarterly data spanning the period 2000 to 2015. All the variables in the model were statistically significant in the short and long run, and hence, they determine net foreign portfolio investment volatility in these countries. The results are consistent with theory and empirical studies such as Akinlo (2004), Glytsos (2005), Ramirez (2006), and Kolodko (2006), amongst others. It was found that prices, real GDP, world GDP and money supply have a positive long-run effect on net foreign portfolio investment volatility in the SADC countries. Conversely, interest rates have a negative impact on net foreign portfolio investment volatility in these countries. This finding is in line with general expectations, economic theory and empirical evidence as indicated in Neumeyer and Perri (2005).

Furthermore, the P-ARDL model provides some evidence of the existence of co-integration between foreign portfolio investment volatility and the other variables in the model. Co-integration exists when the relationship between two time series' variables exhibits a constant pattern in the long run. These findings are in line with empirical studies such as Giuliano and Ruiz-Arranz (2009), Yang (2008) and Li and Liu (2005), amongst others. Moreover, the results revealed a significant negative value of the ECT and a comparatively high speed of adjustment of $73 \%$ at which disequilibrium in the short run can be restored back to equilibrium in the long run. These findings are supportive of Kutu and Ngalawa (2016), Waliullah and Rabbi (2011) and Banerjee et al. (1998) who contended that a highly significant ECT is evidence of the existence of a steady long-run relationship amongst the variables employed in any model.

Policy-makers should embark on policies and programs that promote economic performance in order to attract stable foreign portfolio flows that will lead to stable markets and reduce volatility in the economy. Failure to ensure stable markets and viable investment opportunities would attract speculative and unstable foreign portfolio investment flows that will adversely affect the economic growth of the SADC economies from which escape may be difficult. Overall, it can be concluded that all the variables employed in the system serve as significant predictors of net foreign portfolio investment volatility in both the short and long run in lowincome SADC countries. Economic policy consistency is therefore recommended in order to attract stable investment flows to the region.

It is recommended that future researchers compare the predictors of gross and net portfolio investment volatility, find other means of estimating volatility and include other key variables missed in this study.

\section{Acknowledgements Competing interests}

The authors have declared that no competing interests exist.

\section{Authors' contributions}

Both authors contributed equally to this work. 


\section{Funding information}

This research received no specific grant from any funding agency in the public, commercial or not-for-profit sectors.

\section{Data availability statement}

Data sharing is not applicable to this article as no new data were created or analysed in this study.

\section{Disclaimer}

The views and opinions expressed in this article are those of the authors and do not necessarily reflect the official policy or position of any affiliated agency of the authors.

\section{References}

Ahmed, S. \& Zlate, A., 2014, 'Capital flows to emerging market economies: A brave new world?', Journal of International Money and Finance 48, 221-248. https:// doi.org/10.1016/j.jimonfin.2014.05.015

Akçelik, Y., Başçı, E., Ermişoğlu, E. \& Oduncu, A., 2015, 'The Turkish approach to capital flow volatility', in J.E. Stiglitz \& R.S. Gürkaynak (eds.), Taming capital flows: Capital account management in an era of globalization, pp. 31-54, Palgrave Macmillan, London. https://doi.org/10.1057/9781137427687_3

Akinlo, A.E., 2004, 'Foreign direct investment and growth in Nigeria: An empirical investigation', Journal of Policy Modeling 26, 627-639. https://doi.org/10.1016/j. jpolmod.2004.04.011

Alfaro, L., Kalemli-Ozcan, S. \& Volosovych, V., 2007, 'Capital flows in a globalized world: The role of policies and institutions', in E. Sebastian (ed.), Capital controls and capital flows in emerging economies: Policies, practices and consequences, pp. 19-72, University of Chicago Press, Chicago https://doi.org/10.7208/ chicago/9780226184999.003.0002

Alfaro, L., Kalemli-Ozcan, S. \& Volosovych, V., 2014, 'Sovereigns, upstream capital flows, and global imbalances', Journal of the European Economic Association 12(5), 1240-1284. https://doi.org/10.1111/jeea.12106

Ali, S., Irum, S. \& Ali, A., 2008, 'Whether fiscal stance or monetary policy is effective for economic growth in case of South Asian countries?', The Pakistan Development Review 47(4), 791-799. https://doi.org/10.30541/v47i4llpp.791-799

Al Mamun, M., Sohog, K. \& Akhter, A., 2013, 'A dynamic panel analysis of the financial determinants of CSR in Bangladeshi banking industry', Asian Economic and Financial Review 3, 560.

Banerjee, A., Dolado, J. \& Mestre, R., 1998, 'Error-correction mechanism tests for cointegration in a single-equation framework', Journal of Time Series Analysis 19 , 267-283. https://doi.org/10.1111/1467-9892.00091

Beck, T., Demirgüç-Kunt, A. \& Levine, R., 2009, Financial institutions and markets across countries and over time-data and analysis, World Bank Policy Research Working Paper Series, vol. 1, World Bank, Washington, DC. https://doi.org/10.1596/18139450-4943

Becker, C. \& Noone, C., 2008, Volatility and persistence of capital flows, p. 159, Press \& Communications $\mathrm{CH} 4002$, Basel.

Bleaney, M. \& Greenaway, D., 2001, 'The impact of terms of trade and real exchange rate volatility on investment and growth in sub-Saharan Africa', Journal of Development Economics 65, 491-500. https://doi.org/10.1016/S0304-3878(01) 00147-X

Bluedorn, M.J.C., Duttagupta, R., Guajardo, J. \& Topalova, P., 2013, Capital flows are fickle: Anytime, anywhere (No. 13-183), International Monetary Fund, Washington, DC. https://doi.org/10.5089/9781484389041.001

Broner, F. \& Rigobon, R., 2004, Why are capital flows so much more volatile in emerging than in developed countries?, Central Bank of Chile, Santigo. https:// doi.org/10.2139/ssrn.884381

Broto, C., Díaz-Cassou, J. \& Erce, A., 2011, 'Measuring and explaining the volatility of capital flows to emerging countries', Journal of Banking \& Finance 35, 1941-1953. capital flows to emerging countries', Journal of B
https://doi.org/10.1016/j.jbankfin.2011.01.004

Caballero, R.J. \& Krishnamurthy, A., 2006, 'Bubbles and capital flow volatility: Causes and risk management', Journal of Monetary Economics 53(1), 35-53. https://doi. org/10.1016/j.jmoneco.2005.10.005

Calvo, G.A. \& Mendoza, E.G., 2000, 'Capital-markets crises and economic collapse in emerging markets: An informational-frictions approach', American Economic Review 90(2), 59-64. https://doi.org/10.1257/aer.90.2.59

Caporello, G. \& Maravall, A., 2003, Software TSW, Banco de España, Madrid.

Carrieri, F., Errunza, V. \& Majerbi, B., 2006, 'Does emerging market exchange risk affect global equity prices?', Journal of Financial and Quantitative Analysis 41, 511-540. https://doi.org/10.1017/S0022109000002520

Choong, C.K., Baharumshah, A.Z., Yusop, Z. \& Habibullah, M.S., 2010, 'Private capital flows, stock market and economic growth in developed and developing countries: A comparative analysis', Japan and the World Economy 22, 107-117. https://doi. org/10.1016/j.japwor.2009.07.001
Chudik, A. \& Pesaran, M.H., 2013, 'Large panel data models with cross-sectional dependence: A survey. CAFE Research paper analysis', Journal of Economic Studies dependence: A survey. CAFE Research paper analysis',

Çulha, A., 2006, 'A structural VAR analysis of the determinants of capital flows into Turkey', Central Bank Review 2, 11-35.

Daude, C. \& Fratzscher, M., 2008, 'The pecking order of cross-border investment', Journal of International Economics 74, 94-119. https://doi.org/10.1016/j. jinteco.2007.05.010

Demetriades, P. \& Fielding, D., 2012, 'Information, institutions, and banking sector development in West Africa', Economic Inquiry 50, 739-753. https://doi. org/10.1111/j.1465-7295.2011.00376.x

Devereux, M.B. \& Saito, M., 2006, A portfolio theory of international capital flows, CEPR Discussion Paper No. 5746, pp. 1-38, Hitotsubashi University, Kunitachi. https://doi.org/10.2139/ssrn.922305

De Vita, G. \& Kyaw, K.S., 2008, 'Determinants of FDI and portfolio flows to developing countries: A panel cointegration analysis', European Journal of Economics, Finance and Administrative Sciences 13, 161-168.

Dritsakis, N., 2011, 'Demand for money in Hungary: An ARDL approach', Review of Economics and Finance 1, 1-16.

Engle, R.F. \& Rangel, J.G., 2008, 'The spline-GARCH model for low-frequency volatility and its global macroeconomic causes', Review of Financial Studies 21, 1187-1222. https://doi.org/10.1093/rfs/hhn004

Ersoy, I., 2013, 'The role of private capital inflows and the exchange market pressure on real exchange rate appreciation: The case of Turkey', South African Journal of Economics 81, 35-51. https://doi.org/10.1111/j.1813-6982.2012.01330.x

Ferreira, M.A. \& Laux, P.A., 2009, 'Portfolio flows, volatility and growth', Journal of International Money and Finance 28, 271-292. https://doi.org/10.1016/j. jimonfin.2008.08.010

Forbes, K.J. \& Warnock, F.E., 2012, 'Capital flow waves: Surges, stops, flight, and retrenchment', Journal of International Economics 88, 235-251. https://doi. org/10.1016/j.jinteco.2012.03.006

Friedman, B.M., 1986, Implications of the US net capital inflow, National Bureau of Economic Research Cambridge, MA. https://doi.org/10.3386/w1804

Garg, R. \& Dua, P., 2014, 'Foreign portfolio investment flows to India: Determinants and analysis', World Development 59, 16-28. https://doi.org/10.1016/j. worlddev.2014.01.030

Gerni, C., Kabadayi, B., Yurttancikmaz, Z.C. \& Emsen, O.S., 2013, 'The analysis of competitiveness and economic growth: A case study of transition countries', International Business Research 6, 117. https://doi.org/10.5539/ibr.v6n5p117

Giles, D., 2013, 'ARDL models-part II-bounds tests' [blog], Econometrics Beat: Dave Giles Blog, viewed n.d., from https://davegiles.blogspot.com/2013/06/ardlmodels-part-ii-bounds-tests.html

Giuliano, P. \& Ruiz-Arranz, M., 2009, 'Remittances, financial development, and growth', Journal of Development Economics 90, 144-152. https://doi.org/10.1016/j. jdeveco.2008.10.005

Gligoric, M. \& Jankovic, I., 2013, 'Testing stability of remittance inflows in Serbia', in D. Filipovic \& A.G. Urnaut (eds.), Economic and social development: Book of proceedings, p. 212, Varazdin development and Entrepreneurship Agency, Paris.

Glytsos, N.P., 2005, 'The contribution of remittances to growth: A dynamic approach and empirical analysis', Journal of Economic Studies 32(6), 468-496. https://doi. org/10.1108/01443580510631379

Goldstein, I. \& Razin, A., 2006, 'An information-based trade off between foreign direct investment and foreign portfolio investment', Journal of International Economics 70(1), 271-295. https://doi.org/10.1016/j.jinteco.2005.12.002

Gow, I.D., Ormazabal, G. \& Taylor, D.J., 2010, 'Correcting for cross-sectional and timeseries dependence in accounting research', The Accounting Review 85, 483-512. https://doi.org/10.2308/accr.2010.85.2.483

Gözgör, G. \& Erzurumlu, Y.Ö., 2010, 'Causality relations between foreign direct investment and portfolio investment volatility', MPRA Paper 34352, 172-178.

Haley, U.C., 2001, Multinational corporations in political environments: Ethics, values and strategies, World Scientific, Singapore.

Halicioglu, F., 2005, An ARDL model of aggregate tourism demand for Turkey (No. 0503005), pp. 7-8, University Library of Munich, Germany.

Hegerty, S.W., 2011, 'Do international capital flows worsen macroeconomic volatility in transition economies?', Proceedings of the New York State Economics Association 62, New York State Economics Association, New York, NY.

Ishibashi, S., 2012, 'The segmentation of loan interest rates by regional financial institutions: A panel cointegration analysis', International Review of Business Research Papers 8, 95-110.

Kaltenbrunner, A. \& Painceira, J.P., 2015, 'Developing countries' changing nature of financial integration and new forms of external vulnerability: The Brazilian experience', Cambridge Journal of Economics 39, 1281-1306. https://doi. org/10.1093/cje/beu038

Karimo, T.M. \& Tobi, D.B., 2013, 'Macroeconomic uncertainty and foreign portfolio investment volatility: Evidence from Nigeria', Developing Country Studies 3 , 229-236.

Katircioglu, S.T., 2009, 'Revisiting the tourism-led-growth hypothesis for Turkey using the bounds test and Johansen approach for cointegration', Tourism Management 30, 17-20. https://doi.org/10.1016/j.tourman.2008.04.004

Kirabaeva, K. \& Razin, A., 2012, 'Composition of international capital flows: A survey', in The evidence and impact of financial globalization, CEPR Discussion Paper No. 766, pp. 105-119, National Bureau of Economic Research, Cambridge. https://doi.org/10.1016/B978-0-12-397874-5.00019-1 
Knill, A. \& Lee, B.S., 2014, 'The volatility of foreign portfolio investment and the access to finance of small listed firms', Review of Development Economics 18, 524-542. to finance of small listed firms', Review
https://doi.org/10.1111/rode.12101

Kodongo, O. \& Ojah, K., 2012, 'The dynamic relation between foreign exchange rates and international portfolio flows: Evidence from Africa's capital markets', International Review of Economics \& Finance 24, 71-87. https://doi.org/10.1016/j. iref.2012.01.004

Kolodko, G., 2006, Globalization and its impact on economic development, TIGER Working Paper No. 48, Transformation, Integration and Globalization Economic Research (TIGER), Warsaw. https://doi.org/10.2139/ssrn.961479

Kutu, A.A. \& Ngalawa, H., 2016, 'Dynamics of industrial production in BRICS countries' International Journal of Economics and Finance Studies 8(1), 1-25.

Levchenko, A.A. \& Mauro, P., 2007, 'Do some forms of financial flows help protect against "sudden stops"?', The World Bank Economic Review 21(3), 389-411. https://doi.org/10.1093/wber/lhm014

Li, X. \& Liu, X., 2005, 'Foreign direct investment and economic growth: An increasingly endogenous relationship', World Development 33, 393-407. https://doi.org/ 10.1016/j.worlddev.2004.11.001

Lo Duca, M., 2012, Modelling the time varying determinants of portfolio flows to emerging markets, ECB Working Paper series No. 1468, European Central Bank, emerging markets, ECB Working Paper series No.
Frankfurt. https://doi.org/10.2139/ssrn.1945760

Makoni, P.L., 2014, 'Factors influencing the attraction of foreign direct investment and foreign portfolio investment into African economies', Corporate Ownership \& Control 11, 203. https://doi.org/10.22495/cocv11i4c1p5'

Mercado, Jr, R.V. \& Park, C.Y., 2011, 'What drives different types of capital flows and their volatilities in developing Asia?', International Economic Journal 25, 655-680. https://doi.org/10.1080/10168737.2011.636628

Milesi-Ferretti, G.M. \& Tille, C., 2011, 'The great retrenchment: International capita flows during the global financial crisis', Economic Policy 26, 289-346. https://doi. org/10.1111/j.1468-0327.2011.00263.x

Mody, A., Taylor, M.P. \& Kim, J.Y., 2001, 'Modelling fundamentals for forecasting capital flows to emerging markets', International Journal of Finance \& Economics 6, 201-216. https://doi.org/10.1002/ijfe.159

Mohaddes, M.K. \& Raissi, M.M., 2014, Does inflation slow long-run growth in India?, Cambridge Working Papers in Economics, University of Cambridge, Cambridge. https://doi.org/10.5089/9781498399982.001

Moon, H.R. \& Perron, B., 2004, 'Testing for a unit root in panels with dynamic factors', Journal of Econometrics 122, 81-126. https://doi.org/10.1016/j.jeconom.2003.10.020

Morakinyo, A. \& Sibanda, M., 2016, 'Non-performing loans and economic growth in Nigeria: A dynamic analysis', SPOUDAl-Journal of Economics and Business 66(4), 61-81.

Neumann, R.M., Penl, R. \& Tanku, A., 2009, 'Volatility of capital flows and financial liberalization: Do specific flows respond differently?', International Review of Economics \& Finance 18, 488-501. https://doi.org/10.1016/j.iref.2008.04.005

Neumeyer, P.A. \& Perri, F., 2005, 'Business cycles in emerging economies: The role of interest rates', Journal of Monetary Economics 52, 345-380. https://doi org/10.1016/j.jmoneco.2004.04.011

Nowak-Lehmann, D.F., Herzer, D., Vollmer, S. \& Martínez-Zarzoso, I., 2011 , 'Modelling the dynamics of market shares in a pooled data setting Econometric and empirical issues', Applied Economics 43, 823-835. https://doi org/10.1080/00036840802599925

Obstfeld, M., 2012, 'Financial flows, financial crises, and global imbalances', Journa of International Money and Finance 31, 469-480. https://doi.org/10.1016/j. jimonfin.2011.10.003

Obstfeld,M. \& Rogoff, K., 2009, Global imbalances and the financial crisis: Products of common causes, Discussion Paper No. 7606, Centre for Economic Policy Research, common
London.

Olarewaju, O.M., Sibanda, M. \& Migiro, S.O., 2017, 'Dynamics of Lintner's model in the dividend payment process of Nigerian banks', SPOUDAI - Journal of Economics and Business 67, 79-94.
Oluseye, I.C. \& Gabriel, A.A., 2017, 'Determinants of inclusive growth in Nigeria: An ARDL approach', American Journal of Economics 7, 97-109.

Ostry, J.D., 2012, 'Managing capital flows: What tools to use?', Asian Development Review 29, 82.

Pesaran, M.H., 2007, 'A simple panel unit root test in the presence of cross-section dependence', Journal of Applied Econometrics 22, 265-312. https://doi. org/10.1002/jae.951

Pesaran, M.H. \& Pesaran, B., 1997, Working with Microfit 4.0: Interactive econometric analysis [Windows version], Oxford University Press, London.

Pesaran, M.H., Shin, Y. \& Smith, R.J., 2001, 'Bounds testing approaches to the analysis of level relationships', Journal of Applied Econometrics 16, 289-326. https://doi. org/10.1002/jae.616

Rafindadi, A.A. \& Yosuf, Z., 2013, 'An application of panel ARDL in analysing the dynamics of financial development and economic growth in 38 Sub-Saharan African continents', in Proceedings - Kuala Lumpur international business, economics and law conference, vol. 2, December 02-03, 2013, Hotel Putra, Kuala Lumpur, Malaysia.

Rai, K. \& Bhanumurthy, N., 2004, 'Determinants of foreign institutional investment in India: The role of return, risk, and inflation', The Developing Economies 42, 479-493. https://doi.org/10.1111/j.1746-1049.2004.tb00246.x

Ramirez, M.D., 2006, 'Is foreign direct investment beneficial for Mexico? An empirical analysis, 1960-2001', World Development 34, 802-817. https://doi.org/10.1016/j. worlddev.2006.01.001

Raza, S.A., Shahbaz, M. \& Nguyen, D.K., 2015, 'Energy conservation policies, growth and trade performance: Evidence of feedback hypothesis in Pakistan', Energy Policy 80, 1-10. https://doi.org/10.1016/j.enpol.2015.01.011

Reinhart, C.M. \& Rogoff, K., 2009, This time is different: Eight centuries of financial folly, Princeton University Press, Princeton, NJ. https://doi.org/ $10.1515 / 9781400831722$

Rigobon, R. \& Broner, F.A., 2005, Why are capital flows so much more volatile in emerging than in developed countries?, Working Papers, $\mathrm{N}^{\circ} 328,(328), 1-22$, Central Bank of Chile, Agustinas.

Salisu, A.A. \& Isah, K.O., 2017, 'Revisiting the oil price and stock market nexus: A nonlinear Panel ARDL approach', Economic Modelling 66, 258-271. https://doi. org/10.1016/j.econmod.2017.07.010

Sari, R., Ewing, B.T. \& Soytas, U., 2008, 'The relationship between disaggregate energy consumption and industrial production in the United States: An ARDL approach', Energy Economics 30, 2302-2313. https://doi.org/10.1016/j.eneco. 2007.10.002

Schwert, G.W., 2015, Heteroskedasticity advanced managerial data analysis, viewed n.d., from http://schwert.ssb.rochester.edu/a425/a425_het.pdf.

Shin, Y., Yu, B., \& Greenwood-Nimmo, M., 2014, 'Modelling asymmetric cointegration and dynamic multipliers in a nonlinear ARDL framework,' in W. Horrace \& R. Sickles (eds), The Festschrift in honor of Peter Schmidt: Econometric Methods and Applications, Springer, New York, pp. 281-314. https://doi.org/10.1007/9781-4899-8008-3_9

Waliullah, W. \& Rabbi, F., 2011, 'Effectiveness of monetary policy in Pakistan: Empirical evidences based on boundtest approach', International Journal of Business and Social Science 2, 190-199.

Warnock, F.E. \& Rothenberg, A.D., 2006, Sudden flight and sudden stops, Working Paper, 187, Institute for International Integration Studies, University of Dublin, viewed 23 August 2018, from https://ssrn.com/abstract=946217.

Waqas, Y., Hashmi, S.H. \& Nazir, M.I., 2015, 'Macroeconomic factors and foreign portfolio investment volatility: A case of South Asian countries', Future Business Journal 1, 65-74. https://doi.org/10.1016/j.fbj.2015.11.002

Yang, D., 2008, 'International migration, remittances and household investment: Evidence from Philippine migrants' exchange rate shocks', The Economic Journal 118, 591-630. https://doi.org/10.1111/j.1468-0297.2008.02134.x 